al. Estimation of direct cost and resource allocation in intensive care: correlation with Omega system. Intensive Care Med 1998;24:582-589.

16. Sébille V, Chevret $S$, Valleron AJ. Modeling the spread of resistant nosocomial pathogens in an intensive-care unit. Infect Control Hosp Epidemiol 1997; 18:84-92.

17. Bonten MJ, Hayden MK, Nathan C, van Voorhis J, Matushek M, Slaughter S, et al. Epidemiology of colonisation of patients and environment with vancomycin-resistant enterococci. Lancet 1996;348:1615-1619.

18. Corbella X, Dominguez MA, Pujol M, Ayats J, Sendra M, Pallares R, et al. Staphylococcus aureus nasal carriage as a marker for subsequent staphylococcal infections in intensive care unit patients. Eur J Clin Microbiol Infect Dis 1997;16:351-357.

19. Pujol M, Pena C, Pallares R, Ariza J, Ayats J, Dominguez MA, et al. Nosocomial Staphylococcus aureus bacteremia among nasal carriers of methicillin-resistant and methicillin-susceptible strains. Am J Med 1996;100:509-516.

20. Girou E, Pujade G, Legrand P, Cizeau F, Brun-Buisson C. Selective screening of carriers for control of methicillin-resistant Staphylococcus aureus (MRSA) in high-risk hospital areas with a high level of endemic MRSA. Clin Infect Dis 1998;27:543-550.

21. Jernigan JA, Titus MG, Groschel DH, Getchell-White S, Farr BM. Effectiveness of contact isolation during a hospital outbreak of methicillinresistant Staphylococcus aureus. Am J Epidemiol 1996;143:496-504.

22. Coello R, Jimenez J, Garcia M, Arroyo P, Minguez D, Fernandez C, et al. Prospective study of infection, colonization and carriage of methicillinresistant Staphylococcus aureus in an outbreak affecting 990 patients. Eur J Clin Microbiol Infect Dis 1994:13:74-81.

23. Crowcroft NS, Ronveaux O, Monnet DL, Mertens R. Methicillin-resistant Staphylococcus aureus and antimicrobial use in Belgian hospitals. Infect Control Hosp Epidemiol 1999;20:31-36.

24. Asensio A, Guerrero A, Quereda C, Lizan M, Martinez-Ferrer M. Colonization and infection with methicillin-resistant Staphylococcus aureus: associated factors and eradication. Infect Control Hosp Epidemiol 1996;17:20-28.

25. Malstam J, Lind L. Therapeutic Intervention Scoring System (TISS)-a method for measuring workload and calculating costs in the ICU. Acta Anaesthesiol Scand 1992;36:758-763.

\title{
Epidemic of Corneal Destruction Caused by Plasma Gas Sterilization
}

\section{Gina Pugliese, RN, MS \\ Martin S. Favero, PhD}

Dr. Rose Duffy and colleagues, from the CDC's Hospital Infections Program, recently reported on an epidemiological investigation of corneal destruction caused by instruments sterilized by the Plazlyte Sterilizer (Abtox, Inc, Chicago, IL). This investigation is a classic example of the occurrence of patient injury because of the use of a sterilization system that was not only incompatible with the instruments being sterilized but also produced toxic products by the reaction of the sterilizing chemicals with the instrument materials.

Toxic endothelial cell destruction (TECD) syndrome after intraocular ophthalmic surgery is rare and can result from exposure to a variety of toxins. During January 8 to 14,1998 , six patients developed TECD with corneal edema associated with unreactive or dilated pupils at Hospital A. A case-patient was defined as any hospital A patient with TECD within 24 hours after surgery during January 5 to 14,1998 (epidemic period); a control-patient was any hospital A ophthalmic surgery patient without TECD during the epidemic period. The medical records of hospital A ophthalmology surgery patients during the preepidemic (ie, September 1, 1997-January 4, 1998) and epidemic periods were reviewed. Inductively coupled plasma atomic emission spectrometry was used to detect trace inorganic elements on sterilized surgical instruments. Cannulated surgical instruments and laboratory rinsates were per- fused directly to the corneal endothelium of isolated rabbit and human corneas. Corneal endothelial ultrastructure and swelling were assessed.

The rate of TECD at hospital A was higher during the epidemic than preepidemic period $(6 / 12$ vs $0 / 118, P<.001)$. The only change during the periods was the introduction, on November 5, 1997, of a new sterilization method, AbTox Plazlyte, for sterilization of ophthalmic surgery instruments. Findings from spectrometry revealed that copper and zinc residues were higher in instruments sterilized with Plazlyte than in those sterilized with ethylene oxide (median copper value, $7.64 \mathrm{mg} / \mathrm{L}$ vs $0.14 \mathrm{mg} / \mathrm{L}$, respectively, $P=.02$; median zinc value, $5.90 \mathrm{mg} / \mathrm{L}$ vs $1.35 \mathrm{mg} / \mathrm{L}$, respectively, $P=2$ ). Corneal endothelial perfusion of Plazlyte sterilized-instrument rinsates or laboratory solution with copper and zinc produced irreversible damage, similar to toxic corneal endothelial destruction, to rabbit and human corneas. The authors concluded that the Plazlyte Sterilizer degraded brass to copper and zinc on cannulated surgical instruments, resulting in TECD of the corneas.

Editorial comment: This problem is peculiar to the Plazlyte Sterilizer. During the cycle, a vapor of peracetic acid is produced; this vapor condensed inside the lumens of the instruments that contain copper alloys, producing soluble copper salts such as copper sulfate and copper. acetate. Both forms of these copper salts are water-soluble and toxic. When injected into the rabbit eye, they have been shown to be capable of causing injury. These chemicals were retained in the instruments and produced eye injury. In addition, the specific model of the Plazlyte Sterilizer had never been cleared by the FDA for marketing or for the sterilization of medical devices containing copper or having lumens. The AbTox Plazlyte Sterilizer was withdrawn from the US market during the $\mathrm{CDC}$ investigation. This effect would not be seen by ethylene oxide sterilization or by hydrogen peroxide gas plasma sterilization. With ethylene oxide, the chemical sterilant is removed from the instruments during the post-sterilization aeration process. With hydrogen peroxide gas plasma sterilization (ie, STERRAD Sterilization System, Advanced Sterilization Products, Irvine, CA), the plasma sterilizer uses low-temperature hydrogen gas plasma to sterilize surgical instruments, and the system is dry. The formation of toxic, water-soluble salts such as copper acetate or sulfate would not occur under the oxidizing conditions of this sterilization system, which does not utilize an organic acid that could potentially solubilize copper. There are no known reports of any such occurrences with instruments processed in hydrogen peroxide gas plasma sterilizers, and, given the chemistry involved, none would be expected.

FROM: Duffy RE, Brown SE, Caldwell KL, Lubniewski A, Anderson N, Edelhauser $\mathrm{H}$, et al. An epidemic of corneal destruction caused by plasma gas sterilization. Arch Ophthalmol 2000;118:1167-1176. 